\title{
Future of lion tamarins
}

SIR-On behalf of the International Recovery and Management Committee for the golden-headed lion tamarin, I was delighted to read the News item entitled "Tamarins to go home" (Nature 320, 674; 1986). Tom Milliken, director of WWF Traffic (Japan), is to be complimented on his contribution to the lobbying and diplomacy that has culminated in the announcement that the ten goldenheaded lion tamarins imported illegally into Japan three years ago will be returned to the ownership of the Brazilian government. Conservationists well recognize that the case holds great significance for the future development and implementation of CITES in Japan.

With regard to the reference in the news item that captive breeding programmes are under way at the Rio de Janeiro Primate Centre and at the zoo in Jersey, however, Jersey does not at present have this species included in its successful breeding programmes for golden lion tamarins.

Dr Adelmar Coimbra-Filho, director of the Rio de Janeiro Primate Centre, and I are co-chairmen of the international committee. At the inaugural meeting of the committee at San Diego in June 1985, the main objectives were agreed to be illegally exported or illegally held specimens confiscated or voluntarily replaced under the trusteeship of the Brazilian government and to use the world's best resources to establish a viable captive breeding population under scientific management. The committee advises the Instituto Brasileiro de Desenvoluimento Florestal (IBDF) on the management of the species in captivity.

The release into the wild of these already displaced animals is not recommended at this time; the information available on population, distribution and habitat protection in the Brazilian state of Bahia is insufficient to guarantee survival and could well, through disease, impair the survival of the remnant population.

The recent successful re-introduction of the closely related golden lion tamarin species into the Poco des Antes Biological Reserve in the State of Rio de Janeiro required many years of careful preparation. Similar preparatory research must be carried out before such re-introduction is undertaken with the golden-headed lion tamarin and, in the meantime, a captive self-sustaining population must be secured, with breeding programmes being established at a number of different locations, but managed as an overall single unit.

As a result of a recent ballot among the International Management Committee, of which 50 per cent comprises some of Brazil's leading conservationists, it was unanimously agreed that individuals of the golden-headed lion tamarin species should be made available only to institu- tions that have already had experience with the long-term maintenance and successful propagation of the golden lion tamarin. Priority has been given to selected captive breeding institutions in Brazil, and a list of suitable locations outside Brazil has been drawn up in order to receive individuals that the Brazilian Conservation Authorities consider are surplus to their requirements.

We have great hopes. The golden lion tamarin programme has nurtured a captive population from approximately 70 specimens in 1972 to more than 400 individuals by 1985 , recently recording an annual population growth of $50-60$ animals, on which was based the successful re-introduction programme for this species.

Jeremy J.C. MAllinson Jersey Wildlife Preservation Trust,

Les Augrès Manor,

Trinity, Jersey,

Channel Islands

\section{Is this science?}

SIR-In the past few years, we have witnessed in the pages of Nature a curious debate between those broadly described as "evolutionist" and "creationist", adopting, the former would have us believe, scientific and unscientific arguments respectively. Leaving aside the deterioration into personal abuse, reminiscent more of discussions in a school playground than reasoned debate in a learned journal, it is particularly disturbing to find those purporting to defend the scientific process haplessly resorting to the same sort of emotional and illogical tirades assumed to be the hallmark of the opposition.

In the latest example, J. Richard Wakefield (Nature 320, 392; 1986) asserts that, in contrast to those who believe in a created order, science "accepts nothing on faith". This naivety requires no other comment than to point to a prime example of the author's own article of faith, that "nothing is potentially beyond science". This happens to be a viewpoint that I share. But let us recognize the ill-defined nature of the belief.

Selective awareness is evident in both the statement that "misrepresentation runs rampant in creationism" and the list of human failings in the last paragraph. Is it possible he really believes that no scientist has ever fallen into this category? Few would argue that scientists are perfect. For those who do, a glimpse at the history of palaeontology and the recent debate about cladistic thought at the British Museum (Natural History) ought to convince them otherwise, so "pure" science is probably rather thin on the ground. It seems to me that if colleagues feel the need to defend science against some of the more bizarre claims levelled at it, they must avoid dual standards. It is our responsibility to counter false logic with rigorous argument, not with personal invective or dubious claims to infallibility.

University of Birmingham,

Stuart EgGinton

Department of Physiology,

Vincent Drive,

Birmingham B15 2TJ, UK

\section{Last word on metric}

SIR-My passing remarks mildly critical of metric units (Nature 316, 480; 1985) have provoked your correspondents $(\mathbf{3 1 7}, 10$; 1985; 318, 203, 596; 1985; 319, 8, 93, 716; $1986)$ to imply that I am in league with those who have opposed printing, telescopes, railways, telephones, motion pictures and so on. That is not quite accurate.

While metric units certainly have some role in science and technology, little purpose is served by compelling their everyday use. One might as well argue that since English is now the lingua franca of science, its use should be made compulsory in households the world over. While that might be a fine idea on its own merits, it would likewise be a non sequitur.

Why not simply let people use the units they prefer? Imposing alien units merely fuels the common belief that technocrats seek to control all aspects of life. Such imposition also severs society from its rich linguistic and cultural heritage. It will be remembered that metric units were designed by a group of zealots who hoped to do precisely that, their target being the ancien régime.

DAVID C. JOLLY

Box 931,

Brookline, Massachusetts 02146, USA

This correspondence is now closed. Editor, Nature.

\section{Sex discrimination}

SIR-Joseph Palca's report (Nature 321, $371 ; 1986)$ on the possibility of sequencing the human genome raises the problem of which individual's DNA to use, and suggests possible ways of choosing "him" or "her". While I appreciate this egalitarian phraseology, it is not possible to sequence the whole genome using a female source. Some $2.5 \times 10^{7}$ base pairs of considerable importance to half the world's population would be missing.

Perhaps this conflict between scientific and social requirements could be resolved by selecting an XY female as the source of the DNA.

Howard J. CoOke

MRC Mammalian Genome Unit,

Department of Zoology,

University of Edinburgh,

West Mains Road,

Edinburgh EH9 3JT, UK 